(2)

\section{OPEN ACCESS}

Otolaryngology, Portsmouth Hospitals University NHS Trust, Portsmouth, UK

\section{Correspondence to Aria Amir Ghasemi; ariya243@gmail.com}

Accepted 16 November 2021

\title{
Laryngeal varices: an atypical cause of globus
}

\author{
Tom Ringrose, Jamie Patel, Aria Amir Ghasemi
}

\section{SUMMARY}

Laryngeal varices are rare and are usually associated with vocal cord trauma secondary to excessive use of voice. This report is the first documented case of laryngeal varices secondary to thyroid goitre. This is a report of an 83-year-old woman with a known retrosternal goitre chiefly with symptoms of globus. Retrosternal goitre was found to be compressing the pharyngeal venous plexus causing laryngeal venous structures bilaterally to be engorged along the aryepiglottic folds, arytenoids, posterior commissure and extending in to the postcricoid region. The presence of laryngeal varices carries a significant increased risk of haemorrhage. This case presents an atypical presentation of globus and the first reported case in the literature of laryngeal varices secondary to a thyroid goitre.

\section{BACKGROUND}

Laryngeal varices are rare and are usually associated with vocal cord trauma secondary to voice abuse. Vocal cord varices present a significant increased risk of haemorrhage, reportedly 10 times greater when compared with nonvarix patients. ${ }^{1}$ To our knowledge this is the first report of laryngeal varices secondary to a thyroid goitre.

\section{CASE PRESENTATION}

An 83-year-old woman with a known retrosternal goitre was referred to the ear, nose and throat (ENT) outpatient department at the Queen Alexandra Hospital in Portsmouth, UK with symptoms of globus. She had undergone a thyroidectomy five decades previously for the treatment of a goitre. Recent observational CT imaging was suggestive of laryngeal varices prompting referral to ENT. The patient had no other comorbidities and took no regular medications. The only presenting symptom was that of a sensation of a foreign body in the throat.

Flexible nasendoscopy was performed by a consultant in the ENT department (see figure 1). Examination revealed dilated venous structures bilaterally along the aryepiglottic folds, arytenoids, posterior commissure and extending in to the postcricoid region. Vocal cord movement was normal bilaterally and there was no visible mass lesion. permitted under CC BY-NC. No commercial re-use. See rights and permissions. Published by BMJ.

To cite: Ringrose T, Patel J, Amir Ghasemi A. BMJ Case Rep 2021;14:e246413. doi:10.1136/bcr-2021246413

\section{OUTCOME AND FOLLOW-UP}

The patient was subsequently discussed in the thyroid multi-disciplinary team meeting. The conclusion of the meeting was that the laryngeal varices were likely secondary to the goitre compressing the pharyngeal venous plexus.

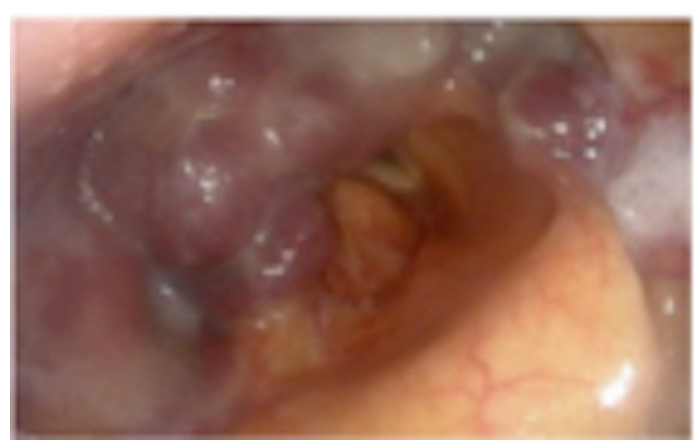

Figure 1 Flexible nasendoscopy showing dilated venous structures bilaterally along aryepiglottic folds, arytenoids, posterior commissure and extending in to the postcricoid region. No mass lesions.

Since the patient was asymptomatic, the recommendation was made for conservative management with an interval CT scan in 1 year. If the patient were to develop new or worsening symptoms then a possible therapy might include treatment with radioactive iodine with the intention of reducing the size of the goitre. If the patient were to develop bleeding, then treatment might include examination under anaesthesia and cauterisation of the bleeding blood vessels.

\section{DISCUSSION}

To our knowledge, this is the first report of laryngeal varices secondary to a thyroid goitre. One previous case of bleeding secondary to tracheal varices caused by compression of a large intrathoracic goitre has been reported in the literature. ${ }^{2}$ Pharyngeal and base of tongue varices have previously been reported in the literature but only secondary to portal hypertension. ${ }^{34}$ The presence of laryngeal varices carries a significant increased risk of haemorrhage. This case presents an atypical presentation of globus and the first reported case in the literature of laryngeal varices secondary to a thyroid goitre.

\section{Learning points}

- Laryngeal varices secondary to a thyroid goitre may present a rare and atypical presentation of globus.

- The presence of laryngeal varices can carry a significant increased risk of haemorrhage.

- Treatment options if very symptomatic might include treatment of the goitre with radioactive iodine or cauterisation of the laryngeal varices. 
Contributors First Author: TR, Department of Otolaryngology, Portsmouth Hospitals University NHS Trust. Co First Author: JP, Department of Otolaryngology, Portsmouth Hospitals University NHS Trust. Second Author: AA-G, Department of Otolaryngology, University Hospital Southampton, NHS Foundation Trust. We hereby certify that submitted work, titled 'Laryngeal Varices: An atypical cause of globus', to BMJ Case Reports journal is written by above three authors. Any work that is not our work has been referenced. All references and sources of information have been clearly cited within the text. We can confirm that TR and JP gathered the clinical data including the photograph following gaining written consent for the patient. TR and JP contributed equally in writing the paper following planning, researching and interpreting the results. Hence TR and JP are considered as first authors. AA-G contributed in writing the paper, editing, optimising the image and submitting the paper to BMJ Case Reports journal. AA-G is considered as the second author.

Funding The authors have not declared a specific grant for this research from any funding agency in the public, commercial or not-for-profit sectors.

Competing interests None declared.

Patient consent for publication Consent obtained directly from patient(s).

Provenance and peer review Not commissioned; externally peer reviewed.
Open access This is an open access article distributed in accordance with the Creative Commons Attribution Non Commercial (CC BY-NC 4.0) license, which permits others to distribute, remix, adapt, build upon this work non-commercially, and license their derivative works on different terms, provided the original work is properly cited and the use is non-commercial. See: http://creativecommons.org/ licenses/by-nc/4.0/.

Case reports provide a valuable learning resource for the scientific community and can indicate areas of interest for future research. They should not be used in isolation to guide treatment choices or public health policy.

\section{REFERENCES}

1 Tang CG-Z, Askin G, Christos PJ, et al. Vocal fold varices and risk of hemorrhage. Laryngoscope 2016;126:1163-8.

2 Lucchini R, Santoprete S, Triola R, et al. Tracheal varices caused by mediastinal compression of a large intrathoracic goiter: report of a case. $G$ Chir 2015;36:26-8

3 Jassar P, Jaramillo M, Nunez DA. Base of tongue varices associated with portal hypertension. Postgrad Med J 2000;76:576-7.

4 Ghaith J, James P, Wong F. A73 pharyngeal varices as a complication of portal hypertension: a case series. J Can Assoc Gastroenterol 2020;3:86-8.

Copyright 2021 BMJ Publishing Group. All rights reserved. For permission to reuse any of this content visit https://www.bmj.com/company/products-services/rights-and-licensing/permissions/

BMJ Case Report Fellows may re-use this article for personal use and teaching without any further permission.

Become a Fellow of BMJ Case Reports today and you can:

- Submit as many cases as you like

- Enjoy fast sympathetic peer review and rapid publication of accepted articles

- Access all the published articles

- Re-use any of the published material for personal use and teaching without further permission

Customer Service

If you have any further queries about your subscription, please contact our customer services team on +44 (0) 2071111105 or via email at support@bmj.com.

Visit casereports.bmi.com for more articles like this and to become a Fellow 